\title{
Students' Perspectives towards Self-Directed Learning out of Classroom
}

\author{
Silmy Arizatul Humaira', \\ ${ }^{1}$ English Education Department \\ Universitas Pendidikan Indonesia \\ Bandung, Indonesia \\ 'humairasilmy@gmail.com
}

\begin{abstract}
One of the critical issues in Indonesia is the tendency of the students to depend very much on their teachers and act passively in the classroom. Meanwhile, in this digital era, students who only depend on the teacher in the class would likely to be left behind and make slower progress on their learning achievement. Due to the limited amount of time in class, the learners are encouraged to be responsible for their own learning and learning independently beyond the classroom called as selfdirected learning. Despite the importance of this aspect, high school students' perspectives toward selfdirected learning, especially in Indonesia, are not clearly explored yet. Therefore, the descriptive qualitative research analysis adapted Knowles's theory (1975) about Self-directed learning (SDL) to analyze the data. The findings show that the students have difficulties in choosing appropriate learning strategy, doing self-assessment and conducting selfreflection. Therefore, this study supports the teacher to promote self-directed learning instruction for successful learning. Furthermore, it is supposed to be a beneficial reference to give new insights on the selfdirected learning practice in Indonesian context.
\end{abstract}

Keywords—self-directed learning; learning autonomy.

\section{INTRODUCTION}

\section{A. Background of the Study}

[1] said that the globalization makes a large economic expansion throughout the world which further affects the way people live and work. He explained that knowledge is developed rapidly and technology changes the way people live this life as they are forced to survive independently without much depending on others. Furthermore, it also impacts the students' role because they must prepare well for their own learning, adapt to the dynamic changes and take initiative independently to solve the problem which is called as SDL (Selfdirected learning) in which the students who are more active would be able to survive well.

Many experts define the term SDL, but most well-known definition is proposed by $[2,4,5,6,8]$ in 1975 who defined SDL as the process in which

\author{
Ismi Ajeng Hurriyah $^{2}$ \\ ${ }^{2}$ English Education Department \\ Universitas Pendidikan Indonesia \\ Bandung, Indonesia \\ ${ }_{\text {ismi.ajeng@gmail.com }}$
}

the learners are able to actively take initiative and responsible for their learning such as to understand their needs, formulate their goals, determine appropriate resources, decide strategies of learning, and evaluate their learning outcome.

[4] stated that classroom is regarded as the "backbone" of language learning but in fact, many students who are successfully master the language are the students who have studied independently. In this case, independent students refer to SDL which has been explained by [5] said that basically the term SDL is based on learning autonomy which refers to "the learners' capacity to take control over their own learning". It means that students are responsible to manage their own learning.

However, in Indonesia, the tendency of the students to depend very much on teacher's instruction reflected in their passive attitude in classroom become the critical problems that need to be solved. It was explained that teacher-centred classroom has very deep influenced towards the teaching practice in Indonesia which affects to the limitation of students' opportunity to be creative and expressive students [6].

Additionally, Wilcox [8] pointed out that SDL refers to autonomous learning and students' responsibility is closely related to higher education. Although, SDL identically refers to adult education as it has been explained in some references as $[2,6]$ but [9] have proven that this kind of learning style is not influenced very much by gender and age of the learners. So, it can be said that SDL might works on high school students, although it seems more challenging.

This study is conducted based on the interest on [2] and [4] argumentation who observed that autonomous learners are more likely to be successful language learners. This study then attempts to investigate how the students in senior high school perceive SDL. Therefore, students' perspectives especially on how the students' deals 
with SDL strategy to improve their English are analyzed.

\section{B. Problem of the Study}

How do the students view self-directed learning (SDL) out of classroom?

\section{Objective of the Study}

To explore students' perspectives toward selfdirected learning (SDL) out of classroom

\section{Significance of the Study}

This study is expected to give a valuable contribution on ELT. Theoretically, the study seeks to explore students' perspectives towards selfdirected learning (SDL) which later will contribute to the literature on English Language Teaching containing of the information about students' perspectives in learning out of the classroom.

\section{E. Scope and Limitation}

The scope of this study is related to students' perspectives especially high school students sit in a language class. Then, the limitation of this study is the number of participants that is relatively small, so this study only represents the results in the small scale that cannot be generalized.

\section{LITERATURE REVIEW}

\section{A. Self-directed learning}

There is a list of skills suggested by [4] in order to learn a language successfully such as planning, implementing, monitoring and evaluating. Meanwhile, planning is the basic step consisting of diagnosing needs, analyzing current skills, formulating goals, deciding resources, and planning what to do next. In this case, [2] also defined selfdirected learning (SDL) as the process includes students to actively take initiative for their own learning such as to identify their needs, goals, resources, strategies of learning, and learning outcome.

\section{B. Components of self-directed learning}

Reference [10] developed the components of self-directed learning in a handout based on Benson in Benson \& White (2016) as described below:

\section{1) Needs analysis}

Students are required to answer a form of selfreport analysis and rate their ability on performing the task. It would be beneficial for them to identify what are the language topics that should be focused based on their needs and priorities [5].

\section{2) Goals and objectives}

Brown [5] pointed out that the goal refers to the general statement containing some aspects that should be achieved in order to get their needs. Thus, it encloses the students' purposes to study. Meanwhile, the objectives are the steps that should be completed in order to reach the goal.

\section{3) Materials selection}

It refers to the students' initiatives to select the materials which are suitable to their needs that can be taken anywhere at any time.

\section{4) Learner strategies}

[5] contended that the students should find the appropriate strategy to be used for studying and practice their skills in order to satisfy their needs.

\section{5) Self-assessment}

According to [5] self-assessment means that the students are required to be able to assess their learning progress in order to know the improvement of their learning and what should be prepared for the next step. It is suggested to ask for help to the expert because it is uneasy for the students to measure their own learning progress, therefore they need to consult to the expert to ask for the measurement.

\section{6) Self-reflection}

Students are supposed to check up all their experiences during the learning process. This step is very important to know any aspects that work well and need to be improved further [5].

\section{The Staged Self-Directed Learning Model}

[3] developed stages of self-directed learners:

\section{1) Dependent student (Learners of low self- direction)}

This kind of students wants explicit instruction from the teacher about what to do, how to do it and when. They passively respond to the teacher.

\section{2) Interested student (Learners of Moderate Self- Direction)}

In this case, students have motivation and confidence. They also have a willingness to do the assignment.

\section{3) Involved student ( Learners of Intermediate Self-Direction)}

The students in this stage have sufficient skill and knowledge and they are ready to explore what to learn by their own. 


\section{4) Self-directed student (Learners of High Self- Direction)}

These students are critical, initiative and independent learners who know their goals and try to use any ways to pursue their goals.

\section{Previous study}

There are some similar studies which also discussed about students' perspectives on SDL. First, a study conducted by [4] concerning on investigating Vietnamese students' self-direction in learning English focused on the listening skills. This study used quantitative data analysis from questionnaires distributed to both teachers and students. The result of the study revealed that the students were not ready to study independently and needed their teachers to instruct them.

Second, [1] also conducted a study concerning on undergraduate students' perspectives on self-directed learning. This study found that the students were aware and able to control their own learning but the faculty and administrators strongly influenced their willingness to study.

Another research conducted by [2] examined students' perspective on autonomous learning project at a community college. The main questions were related to exploring how students view the benefit of SDL and the roles of teachers, varieties of students' different SDL competencies. Through focus group interview, the findings confirmed the utility of SDL towards the improvement of students' knowledge, metacognitive skills, and motivation.

The previous studies above related to SDL of higher education, tertiary education. Those studies analyze the students' and teachers' perspectives from different countries. Due to limited research on SDL in Indonesia, this study attempts to elaborate Indonesian high school students' perspectives on SDL.

\section{RESEARCH}

\section{METHODOLOGY A. Research Design}

This study employed qualitative analysis to investigate the students' perceptions of self-directed learning (SDL). It was non-experimental research where the data were collected through questionnaires and interviews. This study used interpretive analysis to investigate the students' views which became a valuable resource to understand the students' perspectives toward SDL.

\section{B. Data Collection \\ - Participants}

The participants in this study were 30 senior high school students from Senior High School 1 Singosari in Malang. All of them were eleventh grade students from language class. There were 4 males and 26 females participated in this study. The reason of choosing students from language class is because they are supposed to improve their language skills better than the other majors.

\section{Research Instrument}

- Questionnaire

The questionnaire was designed for knowing the students' perspectives on self-directed learning. The questionnaire was adapted from Arndt [5], Grover, Miller, Swearingen, and Wood [6], and Vu \& Shah [4].

- Interview

The interview was intended to explore specific information which was relevant to students' perception. Additionally, in the interview, in-depth information could be obtained with structural questions [9]. In addition to the use of interview in this research, it is believed that interview encourages the participant to unveil classified information [10] and let the researchers to obtain richer and more accurate inferences [11]. The questions were adapted from [1]. Then, the initial draft was reviewed by colleagues to get the feedbacks and prepare for revising questions to make it more appropriate and understandable.

\section{Data Analysis}

The transcribed data which had been labeled then were analyzed by using SDL theory. Then, those data were transformed in the form of charts in order to make the analysis report more clearly. The results of the analysis for both questionnaires and interviews were interpreted qualitatively in depth.

\section{FINDINGS AND DISCUSSION}

\section{A. Findings}

The pie chart below depicted the reasons why the students studying English and the result showed that almost a quarter of overall portion chose other reasons that are unspecified. $10 \%$ of the students only study when the teachers ask them to learn. No one contended that they study because of having free time. More than a half students interested in learning English. It means that most of the students liked studying English. 


\section{Reasons for Studying English}

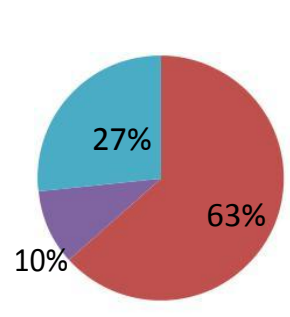

Regarding the frequency of studying English outside the classroom, there were only three percents of all students who said that they learn English very often. More than a quarter of all portion often learn English at home. Another quarter of students learnt English at home sometimes. There are about $10 \%$ of the students who rarely studying English outside the classroom. Then, about $23 \%$ students who admitted that they never learn English beyond the classroom time. Thus, the students did not learn English frequently and it seems that their timing for learning was not regular.

\section{The English Studying Frequency}

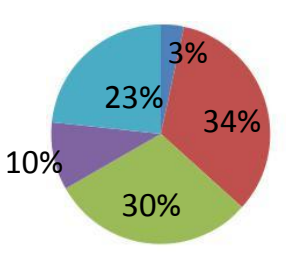

$$
\begin{aligned}
& \text { A. Very often } \\
& \text { B. Often } \\
& \text { - C. Sometimes } \\
& \text { D. Rarely } \\
& \text { E. Never }
\end{aligned}
$$

Talking about the students' time management for studying English, the result revealed that most of the students study at an unspecific time. But there were few students who said that they learn English every day. It can be concluded that their learning was not clearly organized.

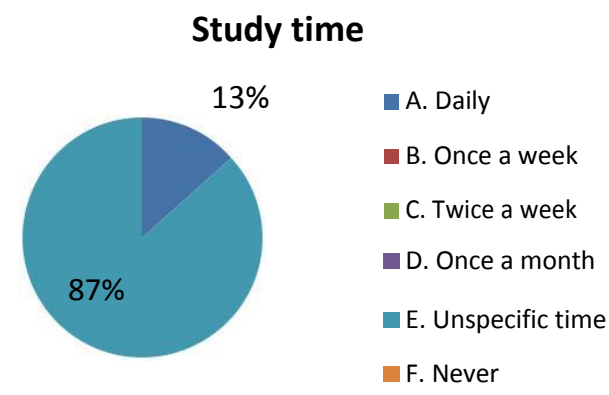

Regarding the time allocated for learning, the students who studied English for approximately 30 minutes and less than 30 minutes are about $40 \%$ and $43 \%$ respectively. Then, only few students who spent approximately an hour to study English at home. It means that most of the students did not spend much time for studying because they only spent 30 minutes or less to study beyond the classroom period.

\section{Time Allotment for Studying English}

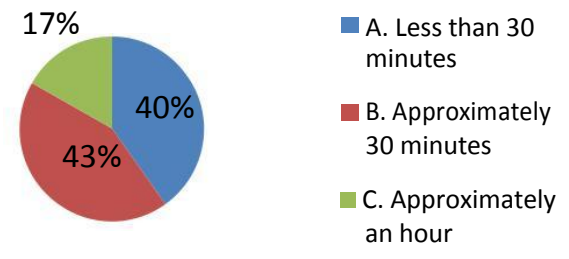

Most of the students said that their challenge in studying at home is caused by the lack of equipment or learning media. Over a third of the students contended that they lack vocabularies. About 30\% students argued that they needed a tutor. Then, few of them stated that they were less motivated to learn English at home. In this case, the students did not know how to use their devices effectively for learning English and lack of vocabularies also become the main problem that needs to be solved later.

\section{Students' Challenges in Studying English}

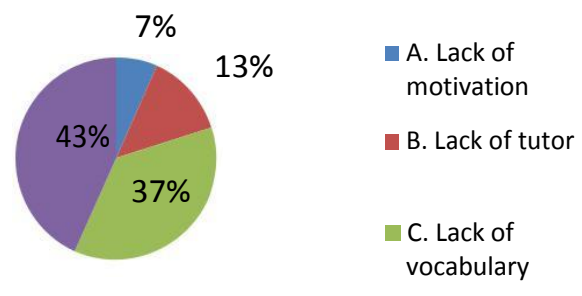

All of the students declared that they love listening to the English music. Almost all students learned English by watching movies. More than a half of students used their electronic devices such as HP, watched online video to learn English, and used social media. Meanwhile, there were some other activities that were chosen by a small number of students. Furthermore, none of the students chose to attend a public seminar, read newspaper and video call. It can be concluded that the students experience language learning beyond the classroom 
in order to improve their English with various ways.

\section{Students' Reflection}

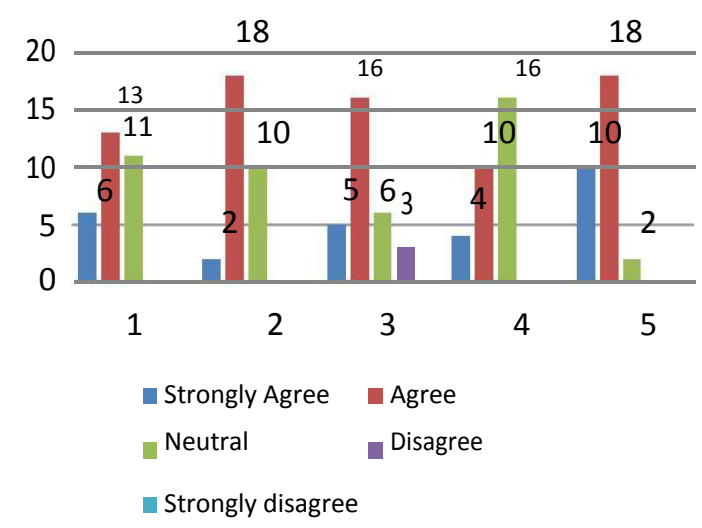

The results gave general information that most of the students are relatively agree with all the statements provided except the fourth statement which discusses students' ability to relate their knowledge to the contexts. It means that the students face difficulties in knowing how to use their knowledge appropriately. As many of them were not sure that they can use their knowledge, it can be said that they need teachers' guidance. Comparing to all the statements, the third statement is the only statement which contains students' disagreement. In this case, a small number of students disagree about doing a consultation to their teacher or sharing with their peers which means that so far they did not consult the teachers or share to their friends.

\section{B. Discussion}

According to the handout developed by Arndt [5], there are 6 components of self-directed learning such as needs analysis, goals and objectives, material selection, learner strategies, selfassessment and self-reflection. The analysis of the data revealed that the students' opinions about English learning are varies.

\section{1) Need Analysis}

When being asked about whether they need to learn English, all students agreed that they need English. Their reasons for learning English are different. They have general reasons and specific reasons. General reasons refer to the function of the important role of English in the International world such as learning English because it is an "International language" which is used throughout the world and become the most popular language used across the world. So they wanted to communicate by using English clearly and correctly. Other students noted that English would give them a chance to get better future. In addition, a student added that those who are able in using English would get so much opportunity. Another student has education reason as she needs English because she wants to answer English tasks well in school. A student has a personal reason that more specific such as because she was interested in learning English so that she chooses language class. Similarly, there are some other students who said that they learn English just because they wanted to do.

\section{2) Goals and objectives}

The goals of learning English for the students are divided into some aspects such as to continue the study into higher education, to get a job, parents' motivation, and individual pride. Students learn English with different purposes. The goals which are related to study refer to the students' opinion that English is learnt as the preparation for them to continue their study in university. Specifically, some of them mentioned that want to continue their study to get a degree in English language and literature. In addition, some of them stated that they want to continue their study either inside or outside the country. Other students' views are related to learning English to get a prestigious job as some of students who pointed out that they wanted to work abroad. They hope that they will get a better future through learning English.

\section{3) Materials selection}

Each student has his or her own favorite activities to do beyond the English classroom activities. A student said that she usually learn English with her sister, watching TV, watching online video from YouTube, singing a song, watching movies, reading books, listening to the music, memorizing vocabularies, online chatting with English speakers, doing English tasks, using mobile phone, and reading novels. It showed that the students have their own preference activities to do. In addition, the analysis from the questionnaires gave additional information which reported that all students choose to listen to the music as their most favorite activity. Then, the second most popular activity is watching movies. Overall, the students seem uninterested in attending public lectures, reading newspaper, and video-calling because none of them chose these activities.

\section{4) Learning Strategies}

There are some strategies that they usually use. Most of them are related to learning vocabularies 
such as translating English sentences, remembering vocabularies, understanding sentence pattern. But there is no further explanation about how they try to make their learning more effective.

\section{5) Self-Assessment}

Almost all students pointed out that they did monitor their language progress. However, it seems that they did not assess their progress by their own. Because they only rely on the English scores which were written in the school report book that they got in each semester.

\section{6) Self-Reflection}

It seemed difficult for them to reflect on what they are learning before. Their answers showed that they do not know how to improve their English and how to fill the gaps in their learning in order to solve the problems they faced.

All of the students argued that English is very much needed. It can be seen that the students have goals and some objectives that support them to learn English although very broad and general. They conducted some activities to improve their English out of the classroom. They are able to select English materials as references to study. But, their strategies in learning English are very limited and not clearly mentioned. Most of them do not do self-assessment because they only depend on the score they got from the school report book. Their self-reflection is very poor because they just do not know how to improve their English and to solve their problems in English. In brief, they were motivated students who need teachers' instruction to guide them to manage their time and learn independently outside the classroom.

Overall, most of the students are regarded as having moderate self-direction. It can be seen from the analysis that the students have high motivation to learn English and they are also confident. Moreover, they do not seriously learn English out of classroom. It can be concluded from their answers that only few of them who learned English every day. They also stated that they study at unspecific time. It means that they do not allocate specific time for studying. In addition, the time allocation for studying is also very limited because most of them answered approximately 30 minutes. Almost a half of the students said the lack of equipment became challenges for them to study.

\section{CONCLUSION}

It is obvious that all of the students agreed that English is very much needed. Their goals and objectives motivated them to learn English beyond the classroom. They conducted some activities to improve their English out of the classroom and they were able to select English materials as references to study. However, their strategies in learning English were very limited and not clearly mentioned. Most of them did not assess their progress individually because they only rely on the score they got from the school report book.

In sum, the findings of this study showed that students have difficulties in choosing appropriate strategies for learning, doing self-assessment, and conducting self-reflection. Therefore, the students need to be the real self-directed learners in order to successfully master the English language. In conclusion, the students were motivated students who need teachers' instruction to guide them to manage their time and learn independently outside the classroom.

\section{REFERENCES}

[1] C. Douglas and S. R. Morris, "Student Perspectives on Self-Directed Learning" Journal of the Scholarship of Teaching and Learning, vol. 14, no. 1, February 2014, pp. 13-25.

[2] F. Du, "Student Perspective of Self-directed Learning" in International Journal for the Scholarship of Teaching and Learning, vol. 7, no. 2, Article 24, 2013, pp. $1-16$

[3] G. O. Grow, "Teaching Learners To Be Self-Directed," in Adult Education Quarterly, vol. 41, no. 3, 1991, 1996, pp. 125-149.

[4] H. Y. Vu and M. Shah, "Vietnamese Students' SelfDirection In Learning English Listening Skill" in Asian Englishes, vol 18, no. 1, 2016, pp. 53-66.

[5] J. D. Arndt, "Self-directed Learning for English Language Learners" in ELF for English as a Lingua Franca Journal, V.3, vol 3, 2017, pp. 38-28.

[6] K.S. Grover, M. T. Miller, B. Swearingen, N. Wood, "An Examination of the Self-Directed Learning Practices of ESL Adult Language Learners," in Journal of Adult Education, vol. 43, no 2, 2014, pp. 12-19.

[7] M. Davis, "Beyond the Classroom: The Role of SelfGuided Learning in Second Language 2, pp. 85-95.

[8] T. Hedge, "Key concepts in ELT," in ELT Journal, vol. 47, no.1, January 1993. Oxford University Press, 1993, pp. 92-93.

[9] J. C. Richards, "Curriculum Development in Language Teaching." United Kingdom: Cambridge University Press, 2001.

[10] S. Troudi \& F. Alwan, "Teachers' Feelings during Curriculum Change in the United Arab Emirates: Opening a Pondora's Box," Teacher Development, vol. 1, pp. 107-121.

[11] M. F. Pajares, "Teachers' Belief and Educational Research: Cleaning up a Messy Construct," Review of Educational Research Journal, vol 62, pp. 307-332.

[12] Zulfikar, T, "The Making of Indonesian Education: An Overview on Empowering Indonesian Teachers," Journal of Indoensian Social Sciences and Humanities, vol. 2, 2009, pp.13-39 